\title{
SPECIES DIFFERENCES IN THE LECTIN-BINDING SITES ON THE ZONA PELLUCIDA OF RODENT EGGS
}

\author{
T. OIKAWA, ${ }^{*}$ R. YANAGIMAGHI* AND G. L. NICOLSON $\dagger$ \\ *Department of Anatomy and Reproductive Biology, University of Hawaii \\ School of Medicine, Honolulu, Hawaii 96822, and †Cancer Council and \\ Electron Microscopy Laboratories, The Salk Institute for Biological Studies, \\ San Diego, California 92112, U.S.A.
}

\section{(Received 12th September 1974)}

Mammalian eggs are surrounded by a moderately thick transparent coat, the zona pellucida, which is believed to be an important site of sperm recognition and of the block to polyspermy (Braden, Austin \& David, 1954; Austin, 1961; Dickmann, 1962; Yanagimachi, 1964; Barros, 1968; Barros \& Yanagimachi, 1972; Hanada \& Chang, 1972; Hartmann, Gwatkin \& Hutchison, 1972; Yanagimachi, 1972; Gwatkin, Williams, Hartmann \& Kniazuk, 1973; Hartmann \& Hutchison, 1974). Little is known of the molecular structure of the zona pellucida, but available evidence indicates that it is composed of glycoproteins or glycopeptides (Braden, 1952; Konecny, 1959; Stegner \& Wartenberg, 1961; Lowenstein \& Cohen, 1964; Jacoby, 1962; Soupart \& Noyes, 1964; Fléchon, 1970; Inoue \& Wolf, 1974; Kang, 1974). Previously we found that the hamster zona pellucida contains receptors for a variety of plant lectins, glycoproteins that bind to specific saccharide determinants (Oikawa, Yanagimachi \& Nicolson, 1973; Oikawa, Nicolson \& Yanagimachi, 1974; Nicolson, Yanagimachi \& Yanagimachi, 1975). Some of these lectins can bind to the zona pellucida and induce egg agglutination and/or cause changes in the ability of the exterior region of the zona to scatter visible light (Oikawa et al., 1973, 1974; Oikawa, Nicolson \& Yanagimachi, 1975). We report here that rodent eggs show speciesspecific differences in lectin-induced agglutination and light scattering properties of their zonae pellucidae when treated with Ricinus communis agglutinin I (RGAI), which recognizes $\beta$-linked D-galactose residues (Nicolson \& Blaustein, 1972; Nicolson \& Lacorbier, 1973), or wheat germ agglutinin (WGA), which recognizes N-acetyl-D-glucosamine and sialic acid residues (Burger \& Goldburg, 1967; Greenaway \& LeVine, 1973).

Unfertilized eggs of the golden hamster, rat (Fisher) and mouse (Swiss albino) were obtained as follows. Adult hamster females were injected intraperitoneally with 20 to 30 i.u. PMSG (Ayerst, New York) on the morning of ovulation. This was followed by an intraperitoneal injection of 20 to 30 i.u. HCG (Ayerst) in the evening 2 days later. Adult mice were injected with 5 to 10 i.u. PMSG regardless of the stage of their oestrous cycle followed by an injection of 5 to 10 i.u. HCG $48 \mathrm{hr}$ later. Prepubertal rats were injected with 20 to 30 i.u. PMSG 
followed by an injection with 20 to 30 i.u. HCG 48 to $56 \mathrm{hr}$ later. Between 15 and $18 \mathrm{hr}$ after injection of $\mathrm{HCG}$, the animals were killed and their oviducts were flushed with Tyrode's solution to collect eggs. The eggs were freed from the surrounding cumulus cells by treating them for 10 to $15 \mathrm{~min}$ at $25^{\circ} \mathrm{C}$ with Tyrode's solution containing $0.1 \%$ crystalline bovine serum albumin (Reheis Chem. Co., Chicago, Illinois) and $0 \cdot 1 \%$ bovine testicular hyaluronidase (300 USP units/mg: Nutritional Biochem., Cleveland, Ohio). After they had been rinsed with Tyrode's solution containing $0.1 \%$ serum albumin, the eggs were placed in albumin-saline (0.01 $\mathrm{m}$-tris- $\mathrm{HCl}: 0.9 \% \mathrm{NaCl}: 0.1 \%$ serum albumin, $\mathrm{pH} 7.4$ ) with various concentrations of RCAI or WGA. The RCAI (mol. wt $120,000)$ was prepared from Hale hybrid strain castor beans by affinity chromatography according to procedures of Nicolson \& Blaustein (1972). The WGA was prepared from an impure wheat germ lipase preparation (Sigma Chem. Co., Saint Louis, Missouri) by affinity chromatography as described by Nicolson \& Lacorbier (1973). After incubation in these solutions for $30 \mathrm{~min}$ at $25^{\circ} \mathrm{C}$,

Table 1. Effects of Ricinus communis I agglutinin on the agglutination and light-scattering property of the zonae pellucidae of the eggs of three rodent species

\begin{tabular}{|c|c|c|c|c|c|c|c|c|}
\hline \multirow[t]{2}{*}{ Species } & \multirow{2}{*}{$\begin{array}{l}\text { No. of females } \\
\text { from which } \\
\text { eggs were } \\
\text { recovered }\end{array}$} & \multirow[t]{2}{*}{ Experiment } & \multirow{2}{*}{$\begin{array}{c}\text { No. of } \\
\text { eggs } \\
\text { used }\end{array}$} & \multicolumn{5}{|c|}{ Concentration of $R C A I(\mu g / m l)$} \\
\hline & & & & 0 & 3 & 10 & 30 & 100 \\
\hline Hamster & 4 & $\begin{array}{l}\text { Agglutination } \\
\text { Light scattering }\end{array}$ & $\begin{array}{l}43 \\
25\end{array}$ & $\underline{0}$ & $4+$ & $\begin{array}{c}4+ \\
\pm\end{array}$ & $\begin{array}{l}4+ \\
++\end{array}$ & $\begin{array}{r}4+ \\
++t\end{array}$ \\
\hline Mouse & 4 & $\begin{array}{l}\text { Agglutination } \\
\text { Light scattering }\end{array}$ & $\begin{array}{l}40 \\
25\end{array}$ & $\frac{0}{-}$ & $1+$ & $\stackrel{4+}{-}$ & 4+ & $4+$ \\
\hline Rat & 4 & $\begin{array}{l}\text { Agglutination } \\
\text { Light scattering }\end{array}$ & $\begin{array}{l}42 \\
25\end{array}$ & $\frac{0}{-}$ & $\stackrel{2+}{-}$ & $\stackrel{3+}{-}$ & $\stackrel{4+}{+}$ & $\begin{array}{l}4+ \\
++\end{array}$ \\
\hline
\end{tabular}

the eggs were tested for their ability to agglutinate and for changes in the light scattering properties of their zonae pellucidae. For agglutination experiments, the eggs in a lectin solution were aggregated by pushing about ten of them together with a needle. The dishes were then agitated to disperse the aggregates. Agglutination was qualitatively scored from 0 to $4+$ as follows: 0, agitation caused the aggregates to disperse completely; $1+$, aggregates containing two eggs each remained; $2+$, aggregates contained about three to four eggs each; $3+$, aggregates contained four to six eggs each; $4+$, the egg aggregates remained completely agglutinated. Light scattering of the zona pellucida was qualitatively scored under dark field illumination from - to +++ as follows: - , light scattering equivalent to untreated control eggs; + , light scattering slightly greater than controls; ++ , moderate light scattering; +++ , strong or intense light scattering of the exterior region of the zona. Lectin-treated controls contained $0.1 \mathrm{M}$ concentrations of appropriate saccharide inhibitors (lactose for RGAI and $\mathrm{N}$-acetyl-D-glucosamine for WGA).

Treatment of rodent eggs with RGAI demonstrated species differences in the lectin-induced agglutination and light scattering properties of the zona (Table 1). Only $3 \mu \mathrm{g} \mathrm{RCAI} / \mathrm{ml}$ was required to produce $4+$ agglutination of hamster 
eggs, but $10 \mu \mathrm{g} / \mathrm{ml}$ were required for mouse eggs and $30 \mu \mathrm{g} / \mathrm{ml}$ for rat eggs to produce an equivalent agglutination. The hamster zona pellucida also showed the strongest RGAI-induced scattering of visible light $(+++$ at $100 \mu \mathrm{g} / \mathrm{ml})$, while the rat zona pellucida showed intermediate light scattering $(++$ at 100 $\mu \mathrm{g} / \mathrm{ml})$. Mouse eggs failed to show light scattering of their zonae pellucidae after treatment with $100 \mu \mathrm{g} \mathrm{RCAI} / \mathrm{ml}$ in spite of being maximally agglutinated at this lectin concentration. The egg agglutination and light scattering of the zonae pellucidae mediated by RCAI were specific because inclusion of an appropriate saccharide inhibitor $(0.1 \mathrm{M}$-lactose or D-galactose) in RCAI solution completely abolished the effects.

In contrast to RGAI, WGA proved to be a poor agglutinin for rodent eggs (Table 2$)$. Only rat eggs were appreciably agglutinated with WGA $(1+$ at 100 $\mu \mathrm{g} / \mathrm{ml})$. Both hamster and rat eggs showed strong WGA-induced light scattering of their zonae pellucidae $(+++$ at $100 \mu \mathrm{g} / \mathrm{ml})$, and mouse zonae showed moderate WGA-induced light scattering $(++$ at $100 \mu \mathrm{g} / \mathrm{ml}$ ) (Table 2). The agglutination and light scattering of the zonae pellucidae mediated by WGA were specific because inclusion of an appropriate saccharide inhibitor $(0 \cdot 1 \mathrm{M}-\mathrm{N}$ acetyl-D-glucosamine) in WGA solution abolished the effects.

Table 2. Effects of wheat germ agglutinin on the agglutination and light-scattering property of the zonae pellucidae of the eggs of three rodent species

\begin{tabular}{|c|c|c|c|c|c|c|c|c|}
\hline \multirow[t]{2}{*}{ Species } & \multirow{2}{*}{$\begin{array}{l}\text { No. of females } \\
\text { from which } \\
\text { eggs were } \\
\text { recovered }\end{array}$} & \multirow[t]{2}{*}{ Experiment } & \multirow{2}{*}{$\begin{array}{c}\text { No. of } \\
\text { eggs } \\
\text { used }\end{array}$} & \multicolumn{5}{|c|}{ Concentration of $W G A(\mu g / m l)$} \\
\hline & & & & 0 & 3 & 10 & 30 & 100 \\
\hline Hamster & 4 & $\begin{array}{l}\text { Agglutination } \\
\text { Light scattering }\end{array}$ & $\begin{array}{l}40 \\
24\end{array}$ & $\underline{0}$ & $\frac{0}{-}$ & $\begin{array}{l}0 \\
\pm\end{array}$ & $\begin{array}{c}0 \\
++\end{array}$ & $\begin{array}{c}0 \\
+++\end{array}$ \\
\hline Mouse & 4 & $\begin{array}{l}\text { Agglutination } \\
\text { Light scattering }\end{array}$ & $\begin{array}{l}42 \\
25\end{array}$ & $\underline{0}$ & $\underline{0}$ & $\frac{0}{-}$ & $\begin{array}{l}0 \\
+\end{array}$ & $\begin{array}{c}0 \\
++\end{array}$ \\
\hline Rat & 4 & $\begin{array}{l}\text { Agglutination } \\
\text { Light scattering }\end{array}$ & $\begin{array}{l}39 \\
20\end{array}$ & $\underline{0}$ & $\underline{0}$ & $\begin{array}{l}0 \\
+\end{array}$ & $\begin{array}{c}0 \\
++\end{array}$ & $\begin{array}{c}1+ \\
+++\end{array}$ \\
\hline
\end{tabular}

These results indicate that there are species differences in the oligosaccharide lectin receptors on the zonae pellucidae of rat, mouse and hamster eggs. Although the significance of the receptor differences is unknown, it is tempting to speculate that the oligosaccharides on the mammalian zona pellucida are important in species recognition by gametes. It is possible that oligosaccharide residues of the zona glycopeptides have species-specific differences in sequence as well as in the relative amounts of each component, and that these differences are recognized by sperm surface receptors as a means of species recognition at fertilization.

This work was supported by grants from the Population Council, the Ford Foundation and U.S. Public Health Service (HD-03402) (R.Y.) and National Science Foundation (GB-34178) to one of us (G.L.N.). We thank Mrs G. A. Mahi for her assistance in preparation of the manuscript. 


\section{REFERENGES}

Austin, C. R. (1961) The Mammalian Egg. C. C. Thomas, Springfield, Illinois.

BARRos, C. (1968) In vitro capacitation of golden hamster spermatozoa with Fallopian tube fluid of the mouse and rat. F. Reprod. Fert. 17, 203-206.

Barros, C. \& Yanagimachi, R. (1972) Polyspermy-preventing mechanisms in the golden hamster egg. 7. exp. Zool. 180, 251-266.

Braden, A. W. H. (1952) Properties of the membranes of rat and rabbit eggs. Aust. F. sci. Res. B5, $460-471$.

Braden, A. W. H., Austin, G. R. \& David, H. A. (1954) The reaction of the zona pellucida to sperm penetration. Aust. F. biol. Sci. 7, 391-409.

Burger, M. M. \& Goldberg, A. R. (1967) Identification of a tumor-specific determinant on neoplastic cell surfaces. Proc. natn. Acad. Sci. U.S.A. 57, 359-366.

Dickmann, Z. (1962) Experiments on interspecific sperm penetration through the zona pellucida. $\mathcal{F}$. Reprod. Fert. 4, 121-124.

FlÉCHON, J. E. (1970) Nature glycoprotéique des granules corticaux de l'oeuf de la lapin mis en evidence par l'utilisation comparée de techniques cytochemiques ultrastructurales. F. Microscopie, 9, 221242.

Greenaway, P. J. \& LeVine, D. (1973) Binding of N-acetyl-neuraminic acid by wheat germ agglutinin. Nature, Lond. 241, 191-192.

Gwatkin, R. B. L., Williams, D. T., Hartmann, J. F. \& KniazuK, M. (1973) The zona reaction of hamster and mouse eggs: production in vitro by a trypsin-like protease from cortical granules. 7. Reprod. Fert. 32, 259-265.

Hanada, A. \& Chang, M. G. (1972) Penetration of zona-free eggs by spermatozoa of different species. Biol. Reprod. 6, 300-309.

Hartmann, J. F., Gwatkin, R. B. L. \& Hutchison, C. F. (1972) Early contact interactions between mammalian gametes in vitro: evidence that the vitellus influences adherence between sperm and zona pellucida. Proc. natn. Acad. Sci. U.S.A. 69, 2767-2769.

Hartmann, J. F. \& Hutchison, C. F. (1974) Nature of the pre-penetration contact interactions between hamster gametes in vitro. 7. Reprod. Fert. 36, 49-57.

Inoue, M. \& Wolf, D. P. (1974) Solubility properties of the murine zona pellucida. Biol. Reprod. 10, $512-518$.

JACOBy, F. (1962) Ovarian histochemistry. In The Ovary, Vol. 1, pp. 189-245. Ed. S. Zuckerman. Academic Press, New York.

KANG, Y. H. (1974) Development of the zona pellucida in the rat oocyte. Am. F. Anat. 139, 535-566.

Konecny, M. (1959) Etude histochimique de la zona pellucida dans ovules de chatte. C. r. Séanc. Soc. Biol. 153, 893-894.

Lowenstein, J. E. \& Cohen, A. I. (1964) Dry mass, lipid content and protein content of the intact and zona-free mouse ovum. J. Embryol. exp. Morph. 12, 113-121.

Nicolson, G. L. \& BLAustern, J. (1972) The interaction of Ricinus communis agglutinin with normal and tumor cell surfaces. Biochim. biophys. Acta, 266, 543-547.

Nicolson, G. L. \& LACORBIER, M. (1973) Cell contact-dependence increase in membrane D-galactopyranosyl-like residues on normal, but not virus- or spontaneously transformed, murine fibroblasts. Proc. natn. Acad. Sci. U.S.A. 70, 1672-1676.

Nicolson, G. L., Yanagimachi, R. \& Yanagimachi, H. (1975) Ultrastructural localization of lectinbinding sites on the zona pellucida and plasma membranes of mammalian eggs. F. Cell Biol. (in press).

Oikawa, T., Nicolson, G. L. \& Yanagmachi, R. (1974) Inhibition of hamster fertilization by phytoagglutinins. Expl Cell Res. 83, 239-246.

Oikawa, T., Nicolson, G. L. \& Yanagimachi, R. (1975) Trypsin-mediated modification of the zona pellucida glycopeptide structure of hamster eggs. F. Reprod. Fert. 43, 133-136.

Oikawa, T., Yanagimachi, R. \& Nicolson, G. L. (1973) Wheat germ agglutinin blocks mammalian fertilization. Nature, Lond. 241, 256-259.

SOUPART, P. \& NoYEs, R. W. (1964) Sialic acid as a component of the zona pellucida of the mammalian ovum. 7. Reprod. Fert. 8, 251-253.

STEGNER, H. E. \& WARTENBerg, H. (1961) Elektronenmikroskopische und histochemische Untersuchungen ueber Structur und Bildung der Zona Pellucida menschlicher Eizellen. Z. Zellforsch. mikrosk. Anat. 53, 702-713.

Yanagimachi, R. (1964) The behavior of hamster sperm to hamster and mouse ova in vitro. Proc. 5 th Int. Congr. Anim. Reprod. E A.I., Trento, 7, 292-293.

Yanagimachi, R. (1972) Penetration of guinea-pig spermatozoa into hamster eggs in vitro. F. Reprod. Fert. 28, 477-480. 